\title{
AGRO-MORPHOLOGICAL CHARACTERIZATION AND INTRA-VARIETAL DIVERSITY OF AKABARECHILLI (Capsicum spp.) LANDRACES OF NEPAL
}

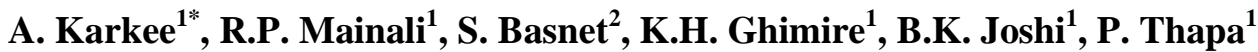 \\ D.S. Shrestha ${ }^{1}$, P. Joshi ${ }^{3}$, P. Pokhrel ${ }^{3}$ and K.K. Mishra ${ }^{1}$ \\ ${ }^{1}$ National Agriculture Genetic Resources Centre, Khumaltar, Lalitpur, Nepal \\ ${ }^{2}$ Himalayan College of Agricultural Science and Technology, Kathmandu, Nepal \\ ${ }^{3}$ Ministry of Agriculture and Livestock Development, Singhdarbar, Kathmandu, Nepal
}

\begin{abstract}
Capsicum (Solanaceae), comprising of sweet and hot chilli pepper, is a globally known spice crop. This genus is well known for its huge genetic diversity at intra- and inter-species level. Diversity among Akabarechilli landraces, a unique Capsicum from Nepal, has not been studied so far. The present study characterized thirty accessions of Akabarechilli using 26 qualitative and 21 quantitative agro-morphological markers at the experimental plots of National Genebank, Khumaltar, Nepal during the summer season of 2018/019. Using principal component analysis, the first- principal components with eigen-values more than 1 contributed $25 \%$ of the variability among accessions for quantitative traits, whereas the first principal components with eigen-values more than 1 contributed $22.2 \%$ of the variability among accessions for qualitative traits. These findings suggested a wide range of morphological variations among the tested accessions. Based on qualitative and quantitative traits, 30 accessions were grouped into 6 distinct clusters by Euclidian distance and average method. Accessions CO-11048 and CO-11050 under cluster-III were round shape fruit type and accessions CO-11044, CO11046 andCO-11047 under cluster-I were high fruiting with longer fruitbearing period and could be utilized for breeding purpose as these are the traits preferred by consumers or processors in Nepalese market.
\end{abstract}

Keywords: Akabarechilli, Capsicum, Diversity index, Landraces,

\footnotetext{
* Corresponding Author: ajayakarkee@gmail.com
} 


\section{INTRODUCTION}

The genus Capsicum is an important fruit vegetable that has been widely consumed throughout the world mainly as a spice (Orobiyi et al., 2017), comprising nearly 40 species (Garcia et al., 2016; Barboza et al., 2019). Out of 40 species of the genus Capsicum, only five species such as $C$. annuum L., C. chinense Jacq., C. frutescens L., C. baccatum L. and C. pubescens Ruiz and Pav. have been cultivated (Costa et al., 2006). Among cultivated species, C. annuum, C. microcarpum (Syn C. baccatum), and $C$. frutescens were reported in Nepal (Sugiyama et al., 2018) as local landraces. Landraces are the early cultivated forms of a crop species, evolved from a wild population, and not manipulated by plant breeders (Joshi, 2017). One of the globally important landraces is 'Akabare' of chili pepper (Joshi, 2017). Chilli fruits serve as a source of vitamins (A, B, C, E, K, B2), proteins, lipids, carbohydrates, fibre, and minerals (Ca, P, Fe) (Bhadragoudar and Patil, 2011).

Akabarechilli, aunique Capsicum spp. called 'AkabareKhursani' also known as DalleKhursani is thought to have originated in eastern Nepal (Sugiyama et al., 2018). These chili peppers found to have high similarity to the $C$. annuum group and were located at the border between the $C$. annuum and $C$. frutescens- chinense groups (Konisho et al., 2005). Akabarechilli is an important high-value crop in the eastern hilly regions i.e., Taplejung, Panchthar, Ilam, Dhankuta, Terathum, and Uadayapur districts of Nepal and the area of cultivation is being expanded every year. In Nepal, Chilli was cultivated in 968 ha of land with $7.47 \mathrm{Mt} /$ ha productivity, whereas Akabarechilli were cultivated in 9,195 ha of land with $10.37 \mathrm{Mt} / \mathrm{ha}$ (MOALD, 2021). Locally available Akabarechillies are more or less ball-like structure almost round cherry size which looks green in the immature stage and dark or bright red during the ripening stage. This chilli type is regarded as high-value crop in Nepal, one of the income-generating crops and has been widely consumed as a spice additive in soup, dal or curry or directly consumed as a fresh or fermented pickle. In the eastern hills of Nepal, It is one of the important income generating crops for farmers. Demand for fresh as well as dried powder of akabarechilli is increasing in international market i.e., Indian, Bhutan, Tibet as well as in domestic market has creating an opportunity for Nepalese farmers to grow for commercial scale (Chapagai et al, 2011). Nepalese people believe that the consumption of an excessive amounts of ordinary chilli can cause injury to the stomach but more pungent and hotter 'AkabareKhursani' varieties do not cause stomach upset (Nemoto et al., 2016) and also take these varieties as a medicinal value for curing gastritis (Mainali et al., 2020).

There is huge diversity of native Akabarechilli genetic resources in Nepal; however, they never get priority in crop improvement programs as other local crops (Joshi et al., 2020). Production of Akabarechilli in Nepal faces many problems among which unavailability of improved/registered varieties is the most important. As the chilli is a highly cross-pollinating crop, the major challenges are to stop genetic erosion that is expected to be higher due to mixing its genetic constituents with foreign hybrid 
varieties as well as other local landraces of chilli. Detailed information on the pattern and structure of agro morphological diversity of Akabarechilli is still lacking, thus accurate phenotyping is of paramount importance for identifying useful traits (Newton et al., 2010). It is very important to assess the existing Akabarechilli diversity for its better utilization in the breeding programs. The morphological and agronomic characterization of a crop is an important step in the management of genetic diversity (Manzano et al., 2001; Radhouane, 2004) and for the selection and development of improved varieties (Fraleigh, 1987; Smith et al., 1991).There is a need for extensive characterization, evaluation, and tagging of economically important traits. Hence, the present study aimed to characterize and assess the intravarietal diversity of Akabarechilli landraces collected from the eastern hills of Nepal using agro-morphological traits.

\section{MATERIALS AND METHODS}

\section{Plant materials and site description}

A total of 30 Akabarechilli accessions collected from five districts of eastern Nepal (Table 1) were characterized at the research field of the National Agriculture Genetic Resources Center (NAGRC), Nepal Agricultural Research Council (NARC), Khumaltar from April 2019 to January 2020. The accessions were from 1080 to 2405 $\mathrm{m}$ above sea level (asl) altitudal range. The research field of NAGRC is located at an altitude of $1368 \mathrm{~m}$ asl, the latitude of $27^{\circ} 40^{\prime} \mathrm{N}$ and longitude of $085^{\circ} 20^{\prime} \mathrm{E}$ (Genebank, 2018) representing the sub-tropical mid hill region.

Table 1. Collection site details of Akabarechilli accessions

\begin{tabular}{cllccc}
\hline $\begin{array}{c}\text { Sl. } \\
\text { No. }\end{array}$ & Collection & Collection Site & Latitude & Longitude & Altitude (m) \\
\hline 1 & CO-11044 & Ilam, Pashupatinagar & 26.936 & 88.078 & 1478 \\
2 & CO-11045 & Solukhumbu, Panchan & 27.410 & 86.690 & 1400 \\
3 & CO-11046 & Panchthar, Chilingdin & 27.334 & 86.515 & 1872 \\
4 & CO-11047 & Okhaldhunga, Barnalu & 27.334 & 86.515 & 1910 \\
5 & CO-11048 & Panchthar, Rabi & 26.926 & 87.679 & 1695 \\
6 & CO-11049 & Panchthar, Rabi & 26.936 & 87.694 & 1692 \\
7 & CO-11050 & Khotang, Batase & 27.076 & 86.726 & 1600 \\
8 & CO-11051 & Panchthar, Rabi & 26.936 & 87.694 & 1692 \\
9 & CO-11052 & Panchthar, Rabi & 26.936 & 87.687 & 1692 \\
\hline
\end{tabular}




\begin{tabular}{rllllc}
\hline $\begin{array}{r}\text { S1. } \\
\text { No. }\end{array}$ & Collection & Collection Site & Latitude & Longitude & Altitude (m) \\
\hline 10 & CO-11053 & Khotang, Diktel & 27.257 & 86.765 & 1880 \\
11 & CO-11054 & Panchthar, Pauwasarnath & 27.065 & 87.804 & 1865 \\
12 & CO-11055 & Khotang, Buipa & 27.237 & 86.714 & 1400 \\
13 & CO-11056 & Khotang, Buipa & 27.215 & 86.724 & 1600 \\
14 & CO-11057 & Khotang, Buipa & 27.217 & 86.730 & 1400 \\
15 & CO-11058 & Khotang, Buipa & 27.217 & 86.730 & 1400 \\
16 & CO-11059 & Panchthar, Rabi & 26.936 & 87.693 & 1692 \\
17 & CO-11060 & Ilam, Samalbung & 26.875 & 88.143 & 1705 \\
18 & CO-11061 & Khotang, Buipa & 27.209 & 86.722 & 1450 \\
19 & CO-11062 & Panchthar, Rabi & 26.921 & 87.682 & 1645 \\
20 & CO-11063 & Panchthar, Rabi & 26.921 & 87.682 & 1650 \\
21 & CO-11064 & Panchthar, Pauwasarnath & 27.063 & 87.807 & 2405 \\
22 & CO-11065 & Panchthar, Sarandanda & 26.982 & 87.668 & 1793 \\
23 & CO-11066 & Khotang, Buipa & 27.238 & 86.714 & 1450 \\
24 & CO-11067 & Khotang, Rajapani & 27.237 & 86.694 & 1080 \\
25 & CO-11068 & Khotang, Buipa & 27.215 & 86.724 & 1600 \\
26 & CO-11069 & Ilam, Barbote & 26.959 & 87.919 & 1440 \\
27 & CO-11070 & Solukhumbu, Salyan & 27.410 & 86.660 & 1540 \\
28 & CO-11071 & Panchthar, Rabi & 26.936 & 87.694 & 1692 \\
30 & CO-11072 & Panchthar, Rabi & 26.922 & 86.667 & 1700 \\
\hline
\end{tabular}

\section{Field experiments}

Seed was sown in nurseries on $1^{\text {st }}$ April 2019 , and seedlings of 6-7 leaves were transplanted (40 days after sowing) using $60 \mathrm{~cm}$ row to row and $20 \mathrm{~cm}$ plant to plant distance. FYM at 10 t/ha and $\mathrm{N}: \mathrm{P}_{2} \mathrm{O}_{5}: \mathrm{K}_{2} \mathrm{O}$ at 90:60:60 kg/ha were applied manually during final land preparation (before transplanting). Intercultural operations i.e., irrigation, weeding, etc. and other agronomic practices were done as required. 


\section{Data collection and data analysis}

Morphological data (26 qualitative and 21 quantitative traits) were recorded using the standard descriptors for characterization (IPGRI, AVRDC and CATIE, 1995)

The coefficient of variation $(\mathrm{CV})$ was calculated based on the formula $\mathrm{CV}(\%)=$ (standard deviation/mean values) $\times 100$. Mean values and standard deviation were calculated on the basis of the 5 individual plants or of the 20 randomly harvested fruits (Orobiyi et al., 2017).

Descriptive statistics, Shannon-Weaver diversity index $\left(\mathrm{H}^{\prime}\right)$ (Shannon and Weaver, 1964), and frequency distribution were employed to estimate and analyze the diversity via MS Excel. The Standardized Shannon-Weaver diversity index (H') was calculated using the formula:

$$
\mathrm{H}^{\prime}=\left[\sum(\mathrm{n} / \mathrm{N}) *\{\log 2(\mathrm{n} / \mathrm{N}) *(-1)\}\right] / \log 2 \mathrm{k}
$$

Where, $\mathrm{H}^{\prime}$ is standardized Shannon Weaver diversity index,

$\mathrm{k}$ is the number of phenotypic classes for a character,

$\mathrm{n}$ is the frequency of phenotypic class of that character

and $\mathrm{N}$ is the total number of observations for character.

For the quantitative traits, accessions were divided into 10 phenotypic classes as $<\mathrm{x}-$ $2 \mathrm{sd}, \mathrm{x}-2 \mathrm{sd}, \mathrm{x}-1.5 \mathrm{sd}, \mathrm{x}-1 \mathrm{sd}, \mathrm{x}-0.5 \mathrm{sd}, \mathrm{x}, \mathrm{x}+0.5 \mathrm{sd}, \mathrm{x}-1 \mathrm{sd}, \mathrm{x}-1.5 \mathrm{sd}, \mathrm{x}-2 \mathrm{sd},>\mathrm{x}+2 \mathrm{sd}$ are as the margin of the classes, where $\mathrm{x}$ is average and sd is standard deviation. The diversity index was considered as low $\left(0.10 \leq \mathrm{H}^{\prime} \leq 0.40\right)$, intermediate $\left(0.40 \leq \mathrm{H}^{\prime} \leq 0.60\right)$ or high $\left(\mathrm{H}^{\prime} \geq 0.60\right)$ (Eticha et al., 2005).

The classifications of landraces on the basis of both qualitative and quantitative traits were performed using multivariate principal component analysis (PCA) in MINITAB version 17 (Minitab, 2010). The construction of two-dimensional (2-D) plots was made based on the first two principal components (PCs). For systematic analysis, hierarchical clustering was performed using Euclidean distance and Average method. Distance between clusters were analyzed and reported as a dendrogram of Euclidean distances via MINITAB version 17.

\section{RESULTS AND DISCUSSION}

Characterization of crops based on morphological and agronomic traits are important steps for the management of genetic diversity (Manzano et al., 2001) and this is a prerequisite for the selection of improved varieties (Fraleigh, 1987; Smith et al., 1991). Further, loss of genetic diversity particularly for the local and crosspollinating crops, mainly because of growing mono-genotype or hybrid varieties has prompted the need for accelerated conservation (Joshi, 2017) which in fact demands the detailed characterization of gene bank holdings. Considering this fact, for the first time, detailed characterization of Akabarechilli landraces available at National 
Genebank, Nepal has been made. Diversity assessment based on morphological characters was done using some statistical tools viz descriptive statistics, diversity index, multivariate analysis such as PCA and cluster analysis, that were used by different authors (Orobiyi et al., 2017, Mellidou et al., 2010).

\section{Diversity based on quantitative characters}

Twenty-one (21) quantitative variables of Akabarechilli measured and analyzed. The descriptive statistics (average, minimum, maximum, and standard deviation) and Shannon-Weaver diversity indices $\left(\mathrm{H}^{\prime}\right)$ were used to measure the diversity of the accessions on quantitative characters.

The coefficient of variation ranged from 5.54 (average days to flowering) to 68.44 (average stem length). Out of 21 measured quantitative parameters, 10 have a high coefficient of variation $(\mathrm{CV}>20 \%)$ indicating greater the dispersion or wide range of variability within the same accessions for these variables. Stem diameter, days to flowering, corolla length, anther length, filament length, days to fruiting, fruitbearing period, fruit length, fruit pedicel length, number of locules per fruit, and seed diameter were the parameters that have a low coefficient of variation $(\mathrm{CV}<20 \%)$ (Table 3) indicating dispersion from the mean is minimum and estimate for these traits are more precise. This also suggests minimum variability in the chilli accessions for these traits.

Days to fruiting, the average length of fruit, average width of fruit, the average weight per fruits, average number of fruits per plant, and fruit bearing period, etc are the most important yield attributing characters that contribute production and marketing value of chilli (Orobiyi et al., 2017). These parameters vary respectively from 87 to 121 days (with an average of 106 days), from 1.46 to $2.88 \mathrm{~cm}$ (with an average $2.05 \mathrm{~cm}$ ), from 0.62 to $2.23 \mathrm{~cm}$ (with an average of $1.53 \mathrm{~cm}$ ), from 0.84 to $6.06 \mathrm{gm}$ (with an average of $2.70 \mathrm{gm}$ ), from 24 to 150 fruits (with an average of 76 fruits/plant), from 1.96 to $7.36 \mathrm{~g}$ for 1000 seeds (with an average of $5.45 \mathrm{gm} / 1000$ seeds) and from 105 to 186 days (with an average of 167 days) (Table 2). Except two quantitative trait variables viz. fruit-bearing period and the number of locules per fruit, all other trait variables were recorded to have high diversity as the ShannonWeaver diversity indices $\left(\mathrm{H}^{\prime}\right)$ for them is higher than 0.6 as defined by Eticha et al. (2005). Among the variables, plant height $(\mathrm{cm})$, mature leaf length $(\mathrm{cm})$, stem diameter $(\mathrm{cm})$, filament length $(\mathrm{mm})$, corolla length $(\mathrm{mm})$ recorded to have the highest Shannon-Weaver diversity indices $\left(\mathrm{H}^{\prime}\right)$. The important yield attributing traits such as days to fruiting $\left(\mathrm{H}^{\prime}=0.78\right)$, fruit size including fruit length $\left(\left(\mathrm{H}^{\prime}=0.84\right)\right.$ and fruit width $\left(\mathrm{H}^{\prime}=0.71\right)$, fruit weight (per fruit $)\left(\mathrm{H}^{\prime}=0.74\right)$, average number of fruits per plant $\left(\mathrm{H}^{\prime}=0.83\right)$. However, the diversity indices of fruit-bearing period, the important yield attributing, and market traits were very minimal $\left(\mathrm{H}^{\prime}=0.28\right)$. Higher average Shannon-Weaver diversity indices $\left(\mathrm{H}^{\prime}\right)$ for quantitative characters $(0.76)$ indicates the presence of a higher diversity on studied agro-morphological characteristics (Table 2). 
Table 2. Descriptive statistics and Shannon-Weaver diversity indices (H') for quantitative traits of Akabare accessions

\begin{tabular}{|c|c|c|c|c|c|c|c|}
\hline $\begin{array}{l}\text { Sl. } \\
\text { No. }\end{array}$ & Variable & Minimum & Maximum & Mean & $\mathrm{CV}$ & SD & $\mathrm{H}^{\prime}$ \\
\hline 1 & Plant height $(\mathrm{cm})$ & 50.00 & 179.60 & 127.72 & 21.26 & 27.15 & 0.92 \\
\hline 2 & Plant canopy width $(\mathrm{cm})$ & 32.92 & 129.58 & 78.59 & 24.32 & 19.11 & 0.81 \\
\hline 3 & Stem length $(\mathrm{cm})$ & 3.10 & 35.40 & 13.61 & 68.44 & 9.31 & 0.62 \\
\hline 4 & Stem diameter $(\mathrm{cm})$ & 1.23 & 2.51 & 1.89 & 13.43 & 0.25 & 0.89 \\
\hline 5 & Mature leaf length $(\mathrm{cm})$ & 5.96 & 18.54 & 13.01 & 25.92 & 3.37 & 0.90 \\
\hline 6 & Mature leaf width $(\mathrm{cm})$ & 3.27 & 10.73 & 7.70 & 29.61 & 2.28 & 0.79 \\
\hline 7 & Days to flowering & 83.00 & 111.00 & 98.50 & 5.54 & 5.46 & 0.80 \\
\hline 8 & Number of flower per axil & 1.00 & 2.67 & 1.89 & 20.47 & 0.39 & 0.74 \\
\hline 9 & Corolla length $(\mathrm{mm})$ & 6.35 & 10.88 & 8.52 & 13.31 & 1.13 & 0.86 \\
\hline 10 & Anther length (mm) & 1.89 & 3.11 & 2.39 & 13.67 & 0.33 & 0.82 \\
\hline 11 & Filament length (mm) & 2.11 & 3.78 & 2.95 & 15.47 & 0.46 & 0.87 \\
\hline 12 & Days to fruiting & 87.00 & 121.50 & 106.75 & 8.31 & 8.87 & 0.78 \\
\hline 13 & Fruit-bearing period (d) & 105.00 & 187.00 & 167.00 & 11.47 & 19.09 & 0.28 \\
\hline 14 & Fruit length $(\mathrm{cm})$ & 1.46 & 2.88 & 2.05 & 15.94 & 0.33 & 0.84 \\
\hline 15 & Fruit width $(\mathrm{cm})$ & 0.62 & 2.23 & 1.53 & 32.20 & 0.49 & 0.71 \\
\hline 16 & Fruit weight $(\mathrm{g})$ & 0.84 & 6.08 & 2.70 & 38.17 & 1.03 & 0.74 \\
\hline 17 & Fruit pedicel length $(\mathrm{cm})$ & 2.06 & 3.45 & 2.62 & 15.18 & 0.40 & 0.86 \\
\hline 18 & Number of locules & 1.10 & 2.95 & 2.40 & 18.02 & 0.43 & 0.35 \\
\hline 19 & Seed diameter $(\mathrm{mm})$ & 3.26 & 4.91 & 4.26 & 9.97 & 0.43 & 0.80 \\
\hline 20 & 1000-seed weight (g) & 1.96 & 7.36 & 5.45 & 23.95 & 1.30 & 0.82 \\
\hline 21 & Number of fruit per plant & 24 & 150 & 76 & 46.67 & 35.59 & 0.83 \\
\hline
\end{tabular}

$\mathrm{CV}=$ Coefficient of variation, $\mathrm{SD}=$ Standard deviation, $\mathrm{H}^{\prime}=$ Shannon-Weaver diversity indices

\section{Diversity based on qualitative characters}

Descriptor states, their frequency, and proportions as well as Shannon-Weaver diversity indices for each qualitative trait are given in Table 3. Among 26 qualitative variables, 24 are found to be polymorphic while two variables such as corolla spot color and corolla shape are found monomorphic. The diversity index $\left(\mathrm{H}^{\prime}\right)$ ranged from 0 to 0.96 with a mean value of 0.50 , indicating medium diversity is present in the collection of Akabarechilli for the qualitative traits. The diversity index $\left(\mathrm{H}^{\prime}\right)$ for 13 variables was found high, while the diversity index for 4 variables were found intermediate. Among 13 variables with high diversity index, some variables which might represent consumer-preferred qualitative traits such as fruit color at the mature stage $\left(\mathrm{H}^{\prime}=0.62\right)$, fruit shape $(0.68)$, fruit surface $(0.96)$, etc. have higher diversity index indicating their potential uses in the future breeding program. 
Higher $\mathrm{H}^{\prime}$ value was found on some characters such as plant growth habit, branching habit, leaf density, leaf shape, fruit surface, flower position, filament color, fruit color at a mature stage, fruit shape, seed color and seed surface while intermediate $\mathrm{H}^{\prime}$ value were found for stem shape, leaf color, fruit shape at pedicel attachment, fruit shape at the blossom end, and seed size. However, relatively lower $\mathrm{H}^{\prime}$ values was found for stem color, stem pubescence, corolla color, anther color, stigma exertion, calyx margin, neck at base of fruit, and fruit blossom end appendage. All accessions have a white colored spot and rotate shape corolla meaning no diversity with $\mathrm{H}^{\prime}=0$.

Table 3. Descriptor states, their frequency, and proportion of phenotypic classes and $\mathrm{S}-\mathrm{W}$ diversity index $\left(\mathrm{H}^{\prime}\right)$ for 26 qualitative traits of Akabarechilli

\begin{tabular}{|c|c|c|c|c|c|}
\hline S1. No. & Characters & $\mathrm{H}^{\prime}$ & Observed phenotypic class & Frequency & Proportion, $\%$ \\
\hline \multirow{2}{*}{1} & \multirow{2}{*}{ Stem colour } & \multirow{2}{*}{0.28} & Green & 4 & 13.3 \\
\hline & & & Green with & 26 & 86.7 \\
\hline \multirow{2}{*}{2} & \multirow{2}{*}{ Stem shape } & \multirow{2}{*}{0.56} & Cylindrical & 9 & 30.0 \\
\hline & & & Angled & 19 & 63.3 \\
\hline \multirow{2}{*}{3} & \multirow{2}{*}{ Stem pubescence } & \multirow{2}{*}{0.30} & Sparse & 27 & 90.0 \\
\hline & & & Intermediate & 3 & 10.0 \\
\hline \multirow{3}{*}{4} & \multirow{3}{*}{ Plant growth habit } & \multirow{3}{*}{0.75} & Prostrate & 6 & 20.0 \\
\hline & & & Intermediate & 14 & 46.7 \\
\hline & & & Erect & 10 & 33.3 \\
\hline \multirow{3}{*}{5} & \multirow{3}{*}{ Branching habit } & \multirow{3}{*}{0.84} & Sparse & 4 & 13.3 \\
\hline & & & Intermediate & 18 & 60.0 \\
\hline & & & Dense & 8 & 26.7 \\
\hline \multirow{3}{*}{6} & \multirow{3}{*}{ Leaf density } & \multirow{3}{*}{0.83} & Sparse & 6 & 20.0 \\
\hline & & & Intermediate & 19 & 63.3 \\
\hline & & & Dense & 5 & 16.7 \\
\hline \multirow{3}{*}{7} & \multirow{3}{*}{ Leaf colour } & \multirow{3}{*}{0.51} & Light green & 8 & 26.7 \\
\hline & & & Green & 8 & 26.7 \\
\hline & & & Dark green & 14 & 46.6 \\
\hline \multirow{3}{*}{8} & \multirow{3}{*}{ Leaf shape } & \multirow{3}{*}{0.79} & Deltoid & 20 & 66.6 \\
\hline & & & Ovate & 5 & 16.7 \\
\hline & & & Lanceolate & 5 & 16.7 \\
\hline \multirow{3}{*}{9} & \multirow{3}{*}{ Flower position } & \multirow{3}{*}{0.73} & Pendant & 2 & 6.7 \\
\hline & & & Intermediate & 20 & 66.6 \\
\hline & & & Erect & 8 & 26.7 \\
\hline 10 & Corolla colour & 0.30 & White & 11 & 36.7 \\
\hline
\end{tabular}




\begin{tabular}{|c|c|c|c|c|c|}
\hline S1. No. & Characters & $\mathrm{H}^{\prime}$ & Observed phenotypic class & Frequency & Proportion, $\%$ \\
\hline & & & Light yellow & 19 & 63.3 \\
\hline 11 & Corolla spot colour & 0 & White & 30 & 100.0 \\
\hline 12 & Corolla shape & 0 & Rotate & 30 & 100.0 \\
\hline \multirow{3}{*}{13} & \multirow{3}{*}{ Anther colour } & \multirow{3}{*}{0.36} & White & 23 & 76.7 \\
\hline & & & Purple & 6 & 20.0 \\
\hline & & & Green & 1 & 3.3 \\
\hline \multirow{4}{*}{14} & \multirow{4}{*}{ Filament colour } & \multirow{4}{*}{0.61} & White & 1 & 3.3 \\
\hline & & & Green & 8 & 26.7 \\
\hline & & & Blue & 9 & 30.0 \\
\hline & & & Purple & 12 & 40.0 \\
\hline \multirow{3}{*}{15} & \multirow{3}{*}{ Stigma exertion } & \multirow{3}{*}{0.49} & Inserted & 4 & 13.3 \\
\hline & & & Same level & 1 & 3.3 \\
\hline & & & Exerted & 25 & 83.3 \\
\hline \multirow{3}{*}{16} & \multirow{3}{*}{ Calyx margin } & \multirow{3}{*}{0.34} & Entire & 1 & 3.3 \\
\hline & & & Intermediate & 26 & 86.7 \\
\hline & & & Dentate & 3 & 10.0 \\
\hline \multirow{4}{*}{17} & \multirow{4}{*}{$\begin{array}{l}\text { Fruit colour at } \\
\text { mature stage }\end{array}$} & \multirow{4}{*}{0.62} & Orange & 2 & 6.6 \\
\hline & & & Light red & 12 & 40.0 \\
\hline & & & Red & 11 & 36.7 \\
\hline & & & Dark red & 5 & 16.7 \\
\hline \multirow{4}{*}{18} & \multirow{4}{*}{ Fruit shape } & \multirow{4}{*}{0.68} & Almost round & 7 & 23.3 \\
\hline & & & Triangular & 14 & 46.7 \\
\hline & & & Campanulate & 2 & 6.7 \\
\hline & & & Blocky & 7 & 23.3 \\
\hline \multirow{3}{*}{19} & \multirow{3}{*}{$\begin{array}{l}\text { Fruit shape at pedicel } \\
\text { attachment }\end{array}$} & \multirow{3}{*}{0.57} & Truncate & 17 & 56.7 \\
\hline & & & Cordate & 10 & 33.3 \\
\hline & & & Lobate & 3 & 10.0 \\
\hline \multirow{2}{*}{20} & \multirow{2}{*}{ Neck at base of fruit } & \multirow{2}{*}{0.21} & Absent & 29 & 96.6 \\
\hline & & & Present & 1 & 3.3 \\
\hline \multirow{3}{*}{21} & \multirow{3}{*}{$\begin{array}{l}\text { Fruit shape at } \\
\text { blossom end }\end{array}$} & \multirow{3}{*}{0.55} & Pointed & 2 & 6.7 \\
\hline & & & Blunt & 13 & 43.3 \\
\hline & & & Shrunken & 15 & 50.0 \\
\hline \multirow{2}{*}{22} & Fruit blossom end & 021 & Absent & 29 & 96.6 \\
\hline & appendage & 0.21 & Present & 1 & 3.3 \\
\hline 23 & Fruit surface & 0.96 & Smooth & 9 & 30.0 \\
\hline
\end{tabular}




\begin{tabular}{|c|c|c|c|c|c|}
\hline \multicolumn{2}{|c|}{ Sl. No. Characters } & $\mathrm{H}^{\prime}$ & Observed phenotypic class & Frequency & Proportion, $\%$ \\
\hline & & & Semi-wrinkled & 14 & 46.7 \\
\hline & & & Wrinkled & 7 & 23.3 \\
\hline \multirow{3}{*}{24} & \multirow{3}{*}{ Seed colour } & \multirow{3}{*}{0.63} & Straw & 17 & 56.7 \\
\hline & & & Brown & 2 & 6.6 \\
\hline & & & Other & 11 & 36.7 \\
\hline \multirow{2}{*}{25} & \multirow{2}{*}{ Seed surface } & \multirow{2}{*}{0.63} & Smooth & 14 & 46.7 \\
\hline & & & Wrinkled & 16 & 53.3 \\
\hline \multirow{2}{*}{26} & \multirow{2}{*}{ Seed size } & \multirow{2}{*}{0.60} & Intermediate & 19 & 63.3 \\
\hline & & & Large & 11 & 36.7 \\
\hline
\end{tabular}

The high mean value of the Shannon-Weaver index for the quantitative traits $\left(H^{\prime}=0.76\right)$ confirmed high genetic diversity. The further intermediate mean value of Shannon-Weaver index and qualitative traits $\left(\mathrm{H}^{\prime}=0.50\right)$ indicate medium diversity in the collection of Akabarechilli landraces and frequency classes for individual traits with diversity on different traits will have implications for utilization in robust crop improvement and enhancement of genetic potential of Akabarechilli. The estimate of $\mathrm{H}^{\prime}$ considers both richness and evenness of the phenotypic classes of the traits (Yadav et al., 2018). The diversity index has been extensively used in the estimation of diversity in a germplasm collection of barley (Tolbert et al., 1979) and used for measurement and comparison pattern of phenotypic diversity in germplasm collection of wheat (Jardat, 1992; Yang et al., 1991).

\section{Principal component analysis (PCA) of qualitative parameters}

PCA analysis is used to identify the important traits of the data set. The dispersal of accessions was based on the principal component- 1 and Principal component- 2 of qualitative characters representing the existing phenotypic variation within the collection and shows how widely they are spread across the axes (Fig 1A).

The PCA based on the qualitative traits revealed that the first eight PCs with eigen value $>1$ accounted for $74.9 \%$ of the total variance (Table 4). The first PC accounted for $22.2 \%$ of the total variance, the traits mainly influenced by, branching habit, and leaf shape. Likewise, the second PC accounted for $12.1 \%$ of the total variance was mainly influenced by anther color. Similarly, the third PC accounting for $10.2 \%$ of the total variance influenced by stigma exertion, fruit blossom end appendage and. The fourth PC accounted for $7.8 \%$ of the total variance mainly influenced by calyx margin whereas the fifth PC accounted for $6.4 \%$ of the total variance, influenced by fruit shape at the blossom end and seed size. Sixth PC accounted for $6 \%$ of the total variance was influenced by stem color, leaf density, fruit shape and. Only $5.7 \%$ of total variance contributes by seventh PC, influenced mainly by stem pubescence, flower position, filament color, and seed surface while $4.6 \%$ of the total variance covers by eight PC, influenced mainly by stem pubescence. 
Table 4. Principal component analysis for26qualitative traits of Akabarechilli accessions

\begin{tabular}{|c|c|c|c|c|c|c|c|c|}
\hline Qualitative trait & $\mathrm{PC} 1$ & $\mathrm{PC} 2$ & PC3 & PC4 & PC5 & PC6 & PC7 & PC8 \\
\hline Eigenvalue & 5.541 & 3.0355 & 2.5391 & 1.9407 & 1.5972 & 1.4924 & 1.4166 & 1.1568 \\
\hline Proportion & 0.222 & 0.121 & 0.102 & 0.078 & 0.064 & 0.06 & 0.057 & 0.046 \\
\hline Cumulative variance & 0.222 & 0.343 & 0.445 & 0.522 & 0.586 & 0.646 & 0.702 & 0.749 \\
\hline Stem colour & -0.153 & -0.262 & -0.214 & -0.195 & -0.093 & 0.361 & 0.123 & -0.042 \\
\hline Stem shape & -0.198 & -0.295 & -0.15 & -0.022 & -0.399 & -0.094 & 0.03 & 0.197 \\
\hline Stem pubescence & 0.045 & 0.352 & -0.184 & 0.118 & 0.125 & -0.038 & 0.402 & 0.365 \\
\hline Plant growth habit & -0.328 & -0.046 & -0.127 & 0.04 & 0.091 & 0.164 & -0.111 & -0.175 \\
\hline Branching habit & 0.338 & 0.043 & 0.093 & 0.091 & -0.101 & -0.034 & -0.067 & 0.219 \\
\hline Tillering & 0.256 & 0.166 & 0.194 & -0.233 & 0.264 & 0.001 & -0.153 & -0.017 \\
\hline Leaf density & 0.248 & -0.019 & -0.261 & 0.148 & -0.062 & -0.309 & 0.035 & -0.065 \\
\hline Leaf colour & 0.092 & 0.257 & 0.129 & 0.061 & -0.303 & 0.024 & 0.056 & -0.409 \\
\hline Leaf shape & 0.349 & -0.064 & 0.239 & 0.119 & -0.115 & 0.012 & -0.086 & 0.105 \\
\hline Flower position & 0.197 & -0.084 & -0.315 & 0.191 & 0.068 & -0.059 & -0.399 & -0.107 \\
\hline Corolla colour & -0.198 & 0.195 & -0.025 & -0.174 & 0.205 & -0.209 & -0.268 & -0.079 \\
\hline Anther colour & -0.186 & 0.335 & -0.032 & 0.266 & -0.072 & 0.30 & -0.041 & -0.002 \\
\hline Filament colour & 0.155 & -0.234 & -0.032 & -0.267 & 0.092 & -0.081 & 0.424 & -0.278 \\
\hline Stigma exertion & -0.083 & -0.261 & 0.316 & 0.301 & 0.03 & 0.136 & -0.104 & -0.128 \\
\hline Calyx margin & -0.107 & 0.31 & 0.145 & 0.331 & -0.218 & 0.074 & -0.017 & 0.049 \\
\hline $\begin{array}{l}\text { Fruit colour at mature } \\
\text { stage }\end{array}$ & 0.158 & -0.23 & 0.226 & 0.194 & -0.016 & -0.141 & -0.027 & -0.342 \\
\hline Fruit shape & -0.153 & 0.061 & 0.153 & 0.146 & -0.096 & -0.341 & 0.114 & -0.241 \\
\hline $\begin{array}{l}\text { Fruit shape at pedicel } \\
\text { attachment }\end{array}$ & 0.204 & -0.238 & -0.23 & 0.28 & -0.264 & 0.099 & 0.128 & 0.148 \\
\hline Neck at base of fruit & -0.05 & 0.061 & 0.01 & -0.243 & -0.194 & -0.479 & -0.107 & 0.225 \\
\hline $\begin{array}{l}\text { Fruit shape at blossom } \\
\text { end }\end{array}$ & 0.173 & 0.047 & -0.147 & 0.235 & 0.413 & 0.079 & 0.12 & -0.035 \\
\hline $\begin{array}{l}\text { Fruit blossom end } \\
\text { appendage }\end{array}$ & 0.107 & 0.041 & 0.409 & -0.267 & -0.076 & 0.278 & 0.236 & 0.089 \\
\hline Fruit surface & 0.109 & 0.054 & 0.043 & 0.067 & -0.081 & -0.217 & 0.152 & -0.102 \\
\hline Seed colour & 0.156 & 0.192 & -0.366 & -0.17 & -0.072 & 0.158 & -0.066 & -0.337 \\
\hline Seed surface & 0.109 & 0.088 & -0.005 & -0.263 & -0.335 & 0.191 & -0.398 & 0.054 \\
\hline Seed size & -0.164 & -0.272 & 0.13 & 0.091 & 0.306 & 0.01 & -0.222 & 0.261 \\
\hline
\end{tabular}




\section{Principal component analysis of quantitative parameters}

The PCA was performed to estimate the relative importance and contribution of each quantitative trait to the total variance and illustrate the agronomic diversity among the 30 landraces. Table 5 shows the principal components and percentage of contribution of each component to the total variation in the akabarechilli landraces. The distribution of accessions based on the first two principal components shows the phenotypic variations among the accessions used and shows the magnitude of spread towards the axes (Fig 1B).

Table 5. Principal component analysis for 21 quantitative traits of Akabarechilli accessions

\begin{tabular}{|c|c|c|c|c|c|c|}
\hline Quantitative trait & $\mathrm{PC} 1$ & $\mathrm{PC} 2$ & PC3 & PC4 & PC5 & PC6 \\
\hline Eigen value & 5.241 & 3.4296 & 2.4059 & 1.7725 & 1.4817 & 1.3403 \\
\hline Proportion of variance & 0.25 & 0.163 & 0.114 & 0.084 & 0.071 & 0.064 \\
\hline Cumulative & 0.025 & 0.413 & 0.527 & 0.612 & 0.682 & 0.746 \\
\hline Plant height $(\mathrm{cm})$ & 0.298 & -0.231 & 0.147 & 0.198 & -0.02 & -0.034 \\
\hline Plant canopy width (cm) & 0.041 & -0.163 & 0.442 & -0.045 & 0.221 & 0.289 \\
\hline Stem length $(\mathrm{cm})$ & 0.287 & -0.102 & -0.034 & 0.173 & -0.208 & 0.424 \\
\hline Stem diameter $(\mathrm{cm})$ & 0.119 & -0.251 & 0.187 & 0.021 & 0.34 & -0.387 \\
\hline Mature leaf length (cm) & 0.338 & 0.147 & -0.112 & -0.181 & 0.187 & 0.189 \\
\hline Mature leaf width $(\mathrm{cm})$ & 0.376 & 0.134 & -0.113 & -0.116 & 0.187 & 0.134 \\
\hline Days to flowering & 0.366 & 0.082 & 0.19 & -0.068 & -0.159 & -0.083 \\
\hline Number of flower (per axil) & 0.215 & -0.02 & -0.249 & 0.103 & -0.257 & -0.266 \\
\hline Corolla length (mm) & 0.013 & 0.105 & 0.459 & 0.236 & 0.028 & -0.163 \\
\hline Anther length (mm) & 0.207 & -0.135 & 0.112 & 0.112 & 0.259 & -0.301 \\
\hline Filament length $(\mathrm{mm})$ & 0.007 & 0.064 & 0.179 & 0.639 & 0.107 & -0.096 \\
\hline Days to fruiting & 0.347 & 0.09 & 0.213 & -0.067 & -0.194 & 0.064 \\
\hline Fruit-bearing period (d) & -0.01 & -0.236 & 0.066 & -0.232 & -0.44 & -0.086 \\
\hline Fruit length $(\mathrm{cm})$ & 0.038 & 0.39 & 0.006 & -0.201 & 0.153 & 0.05 \\
\hline Fruit width $(\mathrm{cm})$ & -0.235 & -0.237 & -0.268 & 0.233 & 0.094 & 0.005 \\
\hline Fruit weight (g) & -0.068 & 0.352 & -0.033 & -0.02 & 0.258 & 0.45 \\
\hline Fruit pedicel length $(\mathrm{cm})$ & 0.059 & -0.418 & 0.052 & 0.066 & -0.221 & -0.003 \\
\hline Number of locules & 0.116 & -0.111 & -0.271 & -0.161 & 0.244 & -0.311 \\
\hline Seed diameter (mm) & 0.254 & 0.069 & -0.316 & 0.191 & 0.05 & -0.009 \\
\hline 1000-seed weight (g) & 0.261 & -0.073 & -0.249 & 0.324 & 0.223 & 0.049 \\
\hline Number of fruits/plant & 0.058 & -0.417 & -0.083 & 0.115 & -0.291 & -0.109 \\
\hline
\end{tabular}


The six principal components (PCs) with eigenvalue $>1$ accounted for $74.6 \%$ of the entire variability. Specifically, the first component, which accounted for $25 \%$ of the total variation, included leaf length, leaf width, days to flowering, days to fruiting, etc. Important traits such as fruit length, fruit weight was included in the second component with $16.3 \%$ variance. The third component explaining $11.4 \%$ of total variation included plant canopy width, corolla length etc. In principle component four, which described $8.4 \%$ of the total variation, filament length, 1000 seed weight, fruit width showed a large contribution. The last two significant principal components, fifth and sixth, explained $7.1 \%$ and $6.4 \%$ of the total variation, respectively. The fifth component was mainly determined by stem diameter and anther length fruit-bearing periods, whereas the sixth components by stem length.
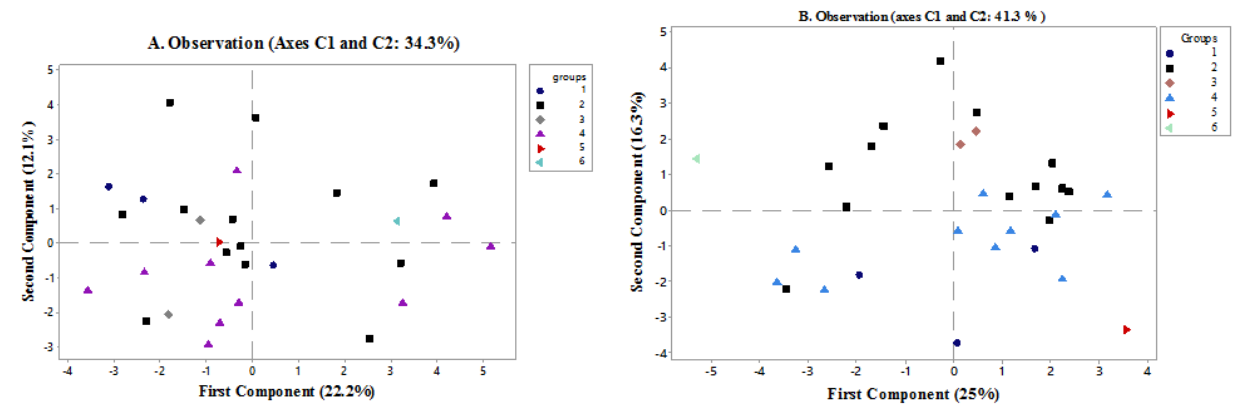

Figure 1.2-D PCA plot of the first two components of the 30 Akabarechilli based on the 26 qualitative traits $(\mathrm{A})$ and the 21 quantitative traits $(\mathrm{B})$

The PCA results show that the most appropriate traits for grouping the Akabarechilli are plant growth habit, branching habit, leaf shape, anther color, leaf length and width, days to flowering, days to fruiting, fruit length, fruit weight, fruit pedicel length, and the number of fruits per plant. By evaluating these traits with the highest values of the diversity index $\left(\mathrm{H}^{\prime}>0.75\right)$ except anther color $\left(\mathrm{H}^{\prime}=0.36\right)$, the first two principal components could efficiently discriminate these landraces, it can signify to serve as an important breeding tool for the characterization of these accessions.

\section{Cluster analysis}

To investigate phenotypic diversity further in 30 akabarechilli landraces, hierarchical cluster analysis on combined qualitative and quantitative traits were used to enable groupings into clusters of genetic similarities, using the Euclidean distance and average linkage methods. The resulting dendrogram revealed six distinct groups: group I is comprised of 3 accessions (10\%), group II of 10 accessions (33.3\%), 
groups III of 13 (43.33\%) accessions, group IV of 2 (6.67\%) accessions, and group V and VI are the solitary clusters with the only accession in each group. The descriptive statistics of the distinct cluster are present in Fig 2.

The landraces included in cluster-I having higher mean value for the number of flowers per axil, fruit-bearing period, fruit width, no of fruit/plant but lower mean value for plant canopy width, days to flowering, and moderate mean values for other agronomic traits. Similarly, the members of Cluster-II have higher mean value for corolla length but moderate mean values for other traits. Likewise, Cluster-III has a higher mean value for the number of locule per fruit and the lowest value for fruit weight. Cluster- $\mathrm{V}$ consisted of one landrace with the higher mean value for the majority of a studied trait while Cluster-VI also having one landrace with lower mean value for majority of studied trait as compared to other clusters (Table 6).

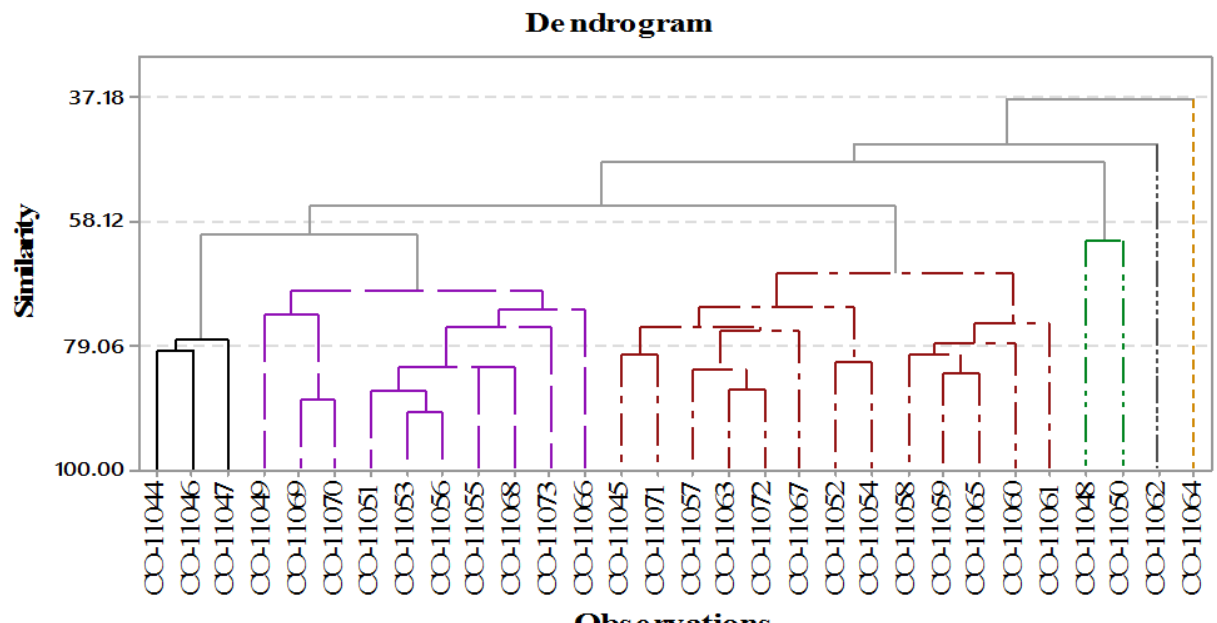

Observations

Figure 2. Dendrogram of 30 akabarechilli accessions based on both 26 qualitative traits and 21 quantitative traits (Similarity level about 60\%) (Minitab 17, statistical package). 
Table 6. Descriptive statistics of quantitative traits within clusters of 30 AkabareChilli accessions

\begin{tabular}{|c|c|c|c|c|c|c|}
\hline Cluster & I & II & III & IV & $\mathrm{V}$ & VI \\
\hline Accessions & $\begin{array}{l}\text { CO-11044, CO- } \\
11046, \text { CO-11047 }\end{array}$ & $\begin{array}{l}\text { CO-11045, CO- } \\
11052, \\
\text { CO-11054, CO- } \\
11057, \\
\text { CO-11058, CO- } \\
11059, \\
\text { CO-11060, CO- } \\
11061, \\
\text { CO-11063, CO- } \\
11065, \\
\text { CO- } 11067, \mathrm{CO}- \\
11071, \\
\text { CO-11072 }\end{array}$ & $\begin{array}{l}\text { CO-11048, CO- } \\
11050\end{array}$ & $\begin{array}{l}\text { CO-11049,CO- } \\
11051, \text { CO- } \\
11053, \text { CO- } \\
11055, \text { CO- } \\
11056, \text { CO- } \\
11066, \text { CO- } \\
11068, \text { CO- } \\
11069, \text { CO- } \\
11070, \text { CO- } \\
11073\end{array}$ & $\begin{array}{l}\mathrm{CO}- \\
11062\end{array}$ & $\begin{array}{l}\mathrm{CO}- \\
11064\end{array}$ \\
\hline Plant height $(\mathrm{cm})$ & $\begin{array}{l}144.4 \pm 5.8(136.3- \\
149.8)\end{array}$ & $\begin{array}{l}121.7 \pm 25.8(85.6- \\
164.0)\end{array}$ & $\begin{array}{l}121.1 \pm 2.8(119.1- \\
123.0)\end{array}$ & $\begin{array}{l}134.5 \pm 17.4 \\
(111.3-156.9)\end{array}$ & 179.6 & 50.0 \\
\hline $\begin{array}{l}\text { Plant canopy } \\
\text { width }(\mathrm{cm})\end{array}$ & $\begin{array}{l}49.6 \pm 13.8(32.9- \\
66.7)\end{array}$ & $\begin{array}{l}76.9 \pm 11.7(62.0- \\
97.4)\end{array}$ & $58.8 \pm 6.8(54.0-63.6)$ & $\begin{array}{l}89.3 \pm 11.4(69.4- \\
103.3)\end{array}$ & 129.6 & 69.6 \\
\hline Stem length $(\mathrm{cm})$ & $16.0 \pm 6.8(9.5-25.4)$ & $\begin{array}{l}11.2 \pm 7.4(3.4- \\
23.5)\end{array}$ & $9.8 \pm 7.3(4.6-15.0)$ & $\begin{array}{l}15.7 \pm 10.1(4.2- \\
33.6)\end{array}$ & 35.4 & 3.1 \\
\hline $\begin{array}{l}\text { Stem diameter } \\
(\mathrm{cm})\end{array}$ & $1.9 \pm 0.2(1.7-2.3)$ & $1.9 \pm 0.2(1.4-2.1)$ & $1.9 \pm 0.1(1.8-2.0)$ & $1.9 \pm 0.3(1.6-2.5)$ & 2.0 & 1.2 \\
\hline $\begin{array}{l}\text { Mature leaf length } \\
(\mathrm{cm})\end{array}$ & $10.0 \pm 3.5(6.0-14.5)$ & $\begin{array}{l}13.7 \pm 3.1(8.4- \\
18.5)\end{array}$ & $16.0 \pm 0.3(15.8-16.2)$ & $\begin{array}{l}12.3 \pm 3.2(7.1- \\
17.2)\end{array}$ & 17.5 & 10.0 \\
\hline $\begin{array}{l}\text { Mature leaf width } \\
(\mathrm{cm})\end{array}$ & $6.6 \pm 2.9(3.3-10.3)$ & $8.0 \pm 2.1(4.4-10.7)$ & $9.7 \pm 0.4(9.4-9.9)$ & $\begin{array}{l}7.3 \pm 2.2(3.4- \\
10.2)\end{array}$ & 10.5 & 4.7 \\
\hline Days to flowering & $\begin{array}{l}96.5 \pm 2.5(93.0- \\
98.5)\end{array}$ & $\begin{array}{l}99.2 \pm 5.0(88.0- \\
105.5)\end{array}$ & $\begin{array}{l}97.3 \pm 3.9(94.5- \\
100.0)\end{array}$ & $\begin{array}{l}99.5 \pm 5.1(91.0- \\
111.0)\end{array}$ & 103.5 & 83.0 \\
\hline $\begin{array}{l}\text { Number of flower } \\
\text { (per axil) }\end{array}$ & $2.4 \pm 0.2(2.3-2.7)$ & $2.0 \pm 0.3(1.5-2.5)$ & $1.8 \pm 0.6(1.3-2.2)$ & $1.7 \pm 0.1(1.0-2.3)$ & 1.8 & 1.7 \\
\hline $\begin{array}{l}\text { Corolla length } \\
(\mathrm{mm})\end{array}$ & $7.5 \pm 1.3(6.4-9.2)$ & $8.7 \pm 0.9(7.1-10.9)$ & $8.1 \pm 1.9(6.7-9.5)$ & $\begin{array}{l}8.7 \pm 1.2(6.8- \\
10.7)\end{array}$ & 8.4 & 8.1 \\
\hline $\begin{array}{l}\text { Another length } \\
(\mathrm{mm})\end{array}$ & $2.4 \pm 0.3(2.0-2.8)$ & $2.4 \pm 0.4(1.9-3.1)$ & $2.3 \pm 0.2(2.1-2.4)$ & $2.5 \pm 0.3(1.9-2.8)$ & 2.2 & 1.9 \\
\hline $\begin{array}{l}\text { Filament length } \\
(\mathrm{mm})\end{array}$ & $2.9 \pm 0.5(2.3-3.5)$ & $2.9 \pm 0.4(2.3-3.6)$ & $3.0 \pm 0.4(2.8-3.3)$ & $3.0 \pm 0.6(2.1-3.8)$ & 3.1 & 2.8 \\
\hline Days to fruiting & $\begin{array}{l}101.8 \pm 2.7(98.0- \\
104.0)\end{array}$ & $\begin{array}{l}107.1 \pm 8.4(92.5- \\
117.5)\end{array}$ & $\begin{array}{l}104.3 \pm 6.0(100.0- \\
108.5)\end{array}$ & $\begin{array}{l}109.2 \pm 9.0(94.5- \\
121.5)\end{array}$ & 117.5 & 87.0 \\
\hline $\begin{array}{l}\text { Fruit-bearing } \\
\text { period (d) }\end{array}$ & $\begin{array}{l}181.0 \pm 3.9(178.0- \\
186.5)\end{array}$ & $\begin{array}{l}166.7 \pm 11.9 \\
(136.0-183.0)\end{array}$ & $\begin{array}{l}107.8 \pm 3.9(105.0- \\
110.5)\end{array}$ & $\begin{array}{l}173.4 \pm 9.2 \\
(155.0-182.5)\end{array}$ & 164.5 & 172.0 \\
\hline Fruit length $(\mathrm{cm})$ & $2.2 \pm 0.2(1.9-2.4)$ & $2.0 \pm 0.4(1.5-2.9)$ & $1.8 \pm 0.2(1.7-1.9)$ & $2.1 \pm 0.2(1.8-2.7)$ & 2.6 & 2.1 \\
\hline Fruit width $(\mathrm{cm})$ & $2.0 \pm 0.2(1.8-2.2)$ & $1.3 \pm 0.5(0.6-2.2)$ & $1.8 \pm 0.1(1.7-1.9)$ & $1.7 \pm 0.4(0.8-2.1)$ & 1.2 & 1.8 \\
\hline Fruit weight (g) & $2.9 \pm 0.6(2.1-3.7)$ & $2.4 \pm 1.1(0.8-5.4)$ & $2.4 \pm 0.6(2.0-2.8)$ & $2.6 \pm 0.4(1.8-3.3)$ & 6.1 & 3.9 \\
\hline $\begin{array}{l}\text { Fruit pedicel } \\
\text { length }(\mathrm{cm})\end{array}$ & $3.1 \pm 0.1(3.0-3.2)$ & $2.5 \pm 0.3(2.1-3.5)$ & $2.3 \pm 0.1(2.2-2.3)$ & $2.8 \pm 0.3(2.1-3.2)$ & 3.4 & 2.1 \\
\hline
\end{tabular}




\begin{tabular}{|c|c|c|c|c|c|c|}
\hline Cluster & I & II & III & IV & $\mathrm{V}$ & VI \\
\hline $\begin{array}{l}\text { Number of } \\
\text { locules }\end{array}$ & $2.5 \pm 0.2(2.2-2.7)$ & $2.4 \pm 0.6(1.1-3.0)$ & $2.6 \pm 0.5(2.2-2.9)$ & $2.5 \pm 0.3(2.1-2.9)$ & 2.2 & 2.1 \\
\hline $\begin{array}{l}\text { Seed diameter } \\
(\mathrm{mm})\end{array}$ & $4.6 \pm 0.1(4.5-4.8)$ & $4.2 \pm 0.4(3.5-4.9)$ & $4.6 \pm 0.4(4.3-4.8)$ & $4.1 \pm 0.5(3.3-4.9)$ & 4.6 & 4.2 \\
\hline $\begin{array}{l}\text { 1000-seed weight } \\
(\mathrm{g})\end{array}$ & $6.0 \pm 0.5(5.3-6.6)$ & $5.1 \pm 0.9(3.2-6.4)$ & $6.7 \pm 0.9(6.1-7.4)$ & $5.5 \pm 1.8(2.0-7.1)$ & 7.1 & 4.4 \\
\hline $\begin{array}{l}\text { Number of } \\
\text { fruits/plant }\end{array}$ & $\begin{array}{l}139.0 \pm 9.9(126.0- \\
150.0)\end{array}$ & $\begin{array}{l}49.1 \pm 12.4(29.0- \\
69.0)\end{array}$ & $\begin{array}{l}55.5 \pm 44.6(24.0- \\
87.0)\end{array}$ & $\begin{array}{l}98.5 \pm 15.5(79.0- \\
120.0)\end{array}$ & 108.0 & 29.0 \\
\hline
\end{tabular}

*value in parenthesis shows the range with in the groups of concerned trait.

Cluster analysis clearly separated 30 Akabarechilli landraces into six groups at $60 \%$ similarity level with the fifth and sixth cluster containing only landraces. On the basis of cluster analysis, Cluster-V was found superior in terms of quantitative character as compared to the other clusters. Orobiyi et al. (2017) state that the most significant attributing characters of chilli were the average weight of fruits, the average number of fruits per plant, the weight of 1000 seeds, average length and width of fruit, and the days to fruiting. Among these quantitative characters, Cluster-V (CO-11062) has the highest value for days to fruiting, fruit length, fruit weight, 1000 seed weight. Similarly, Cluster-I (CO-11044, CO-11046, CO-11047) has a higher fruit weight and the amount of fruits/plant as compared to other clusters. Cluster-VI has the lowest value for most of the quantitative traits as compared to the other clusters. This information could be used in crop improvement programs, particularly for selection and hybrid development.

Not only the yield parameter is important, but there is also another important trait that is essential in the contest of consumer preference and economic point of view, is its fruit shape. People prefer more round shape chilli than any other and have higher demand at the market. The Shannon-Weaver index for fruit shape is recorded high. Cluster analysis showed that fruits of Cluster-III were found more round with a higher number of locules per fruit than others. Whereas Cluster-V has longer fruit size than other groups and other clusters were found intermediate type. These identified materials could be used as materials for the selective breeding programs for concerning traits of interest in the future. Crosses between the members of clusters separated by inter-cluster distances are likely to be beneficial for further improvement (Yatung et al., 2014). The genotypes with larger fruit size were preferred for other chilly types (Dahal et al., 2006) but more round shape type fruit with a specific order type Akabarechilli is preferred by consumers and willing to pay more money.

\section{CONCLUSION}

Agro-morphological variability of akabarechilli landraces collected from eastern hills of Nepal was carried out by its qualitative and quantitative parameters. Combined 
qualitative and quantitative variables classified 30 akabarechilli landraces into six distinct groups. Although, the result of this experiment was obtained from one-year experiments and thus the interaction between environment and genotype, was not measured, but the result of the experiment related to morphological trait was equally important to characterize our accessions, as it helped to estimate variability existed in the landraces which were due to genotype effect between the landraces.

\section{ACKNOWLEDGEMENT}

We would like to thank Nepal Agricultural Research Council for providing the fund and support. Intern and staff of the National Agriculture Genetic Resources Center, Khumaltar, Lalitpur, Nepal are duly acknowledged for their valuable contribution to carry out this experiment.

\section{REFERENCES}

Barboza, G.E., Garcia, C.C., Gonzalez, S.L., Scaldaferro, M. and Reyes, X. (2019). Four new species of Capsicum (Solanaceae) from the tropical Andes and an update on the phylogeny of the genus. Plos One, 14(1):e0209792.

Bhadragoudar, M.R. and Patil, C.G. (2011). Assessment of genetic diversity among Capsicum аппиит L. genotypes using RAPD markers. American Journal of Botany, 10(76):17477-17483.

Chapagai, T.R., Timsina, K.P. and Shrestha, K.P. 2011. Supply chain analysis of Akabarechilli (Capsicum annuum L. Var Cerasiforme Irish) A case of Ilam district of Nepal. The Journal of Economic Concern, 2(4):99-112.

Costa, F.R., Pereira, T.N.S., Vitoria, A.P., deCampos, K.P., Rodrigues, R., daSilva, D.H. and Pereira, M.G. (2006). Genetic diversity among Capsicum accessions using RAPD markers. Crop Breeding and Applied Biotechnology, 6:18-23.

Dahal, K.C., Sharma, M.D., Dhakal, D.D. and Shakya, S.M. (2006). Evaluation of heat tolerant chilli (Capsicum annuиm L.) genotypes in western terai of Nepal. Journal of the Institute of Agriculture and Animal Science, 27:59-64.

Eticha, F., Bekele, E., Belay, G. and Borner, A. (2005). Phenotypic diversity in tetraploid wheat collected from Bale and Wello regions of Ethiopia. Plant Genetic Resources, 3: $35-43$.

Fraleigh, B. (1987). Importance des banques de resources phytogénétiques, In: Amélioration et protection des plant esvivrières tropicales (Editors: C.A. Saint Pierre and Y. Demarly), Quebec, Canada. Pp. 13-18.

Garcia, C.C., Barfuss, M.H., Sehr, E.M., Barboza, G.E., Samuel, R., Moscone, E.A. and Ehrendorfer, F. (2016). Phylogenetic relationships, diversification and expansion of chili peppers (Capsicum Solanaceae). Annals of Botany, 118(1): 35-51.

Genebank. (2018). Annual Report 2074/75 (2017/18). National Agriculture Genetic Resources Centre, NARC. Khumaltar, Lalitpur, Nepal.

IPGRI, AVRDC and CATIE. (1995). Descriptors for Capsicum (Capsicum spp.). International Plant Genetic Resources Institute, Rome, Italy; the Asian Vegetable 
Research and Development Center, Taipei, Taiwan, and the Centro AgronómicoTropical de Investigación y Enseñanza, Turrialba, Costa Rica.

Jardat, A.A. (1992). Estimates of Phenotypic Diversity and Trait Association in Durum Wheat Landraces form Jordan. Journal of Genetics and Breeding, 46:69-76.

Joshi, B.K. (2017). Plant breeding in Nepal: Past, present and future. Journal of Agriculture and Forestry University, 1: 1-33.

Joshi, B.K., Gorkhali, N.A., Pradhan, N., Ghimire, K.H., Gotame, T.P., Prenil, K.C., Mainali, R.P., Karkee, A. and Paneru, R.B. (2020). Agrobiodiversity and its conservation in Nepal. Journal of Nepal Agricultural Research Council, 6: 14-33.

Konisho, K., Minami, M., Matsushima, K. and Nemoto, K. (2005). Phylogenetic relationship and species identification by RAPD analysis in genus capsicum. Horticulture Research (Japan), 4(3): 259-264.

Mainali, R.P., Karkee, A., Thapa, P., Ghimire, K.H., Joshi, B.K. and Mishra, K.K. (2020). Collaborative exploration and collection of native plant genetic resources as assisted by agrobiodiversity fair. Journal of Agriculture and Natural Resources, 3(2): 67-81.

Manzano, A.R., Nodals, R.A.A., Gutiérrez, R.A.I.M., Mayor, F.Z. and Alfonso, C.L. (2001). Morphological and izoensime variability of taro (Colocasiaesculenta L. Schott) germplasm in Cuba. Plant Genetic Resources, 126: 31-40.

Mellidou, L., Krommydas, K., Nianiou-Obeidat, I., Ouzounidou, G., Kalivas, A. and Ganopoulos, I. (2020). Exploring morpho-physiological profiles of a collection of tomato (Soalnumlycopersicum) germplasm using multivariate statistics. Plant Genetic Resources: Characterization and Utilization, 18(2): 88-97

MINITAB, (2010). Minitab 17 Statistical Software. State College, Pennsylvania: Minitab, Inc. Www.minitab.com

MOALD. (2021). Statistical information on Nepalese Agriculture (2019/20). Ministry of Agriculture and Livestock Development, Planning and development cooperation coordination division, Statistics and Analysis Section, Singhdurbar, Kathmandu, Nepal.

Nemoto, K., Matsusima, K., Joshi, B.K., Ghimire, K.H., Suda, G. and Hatakeyama, K. (2016). Collaborative survey of amaranthus and capsicum genetic resources in Nepal, February 2016. AREIPGR, 32: 227-241.

Newton, A.C., Akar, T., Baresel, J.P., Bebeli, P.J., Bettencourt, E., Bladenopoulos, K.V., Czembor, J.H., Fasoula, D.A., Katsiotis, A. and Koutis, K. (2010). Cereal landraces for sustainable agriculture: a review. Agronomy for Sustainable Development,30:237-269.

Orobiyi, A., Loko, L.Y., Sanoussi, F., Agre, A.P., Korie, N., Gbaguidi, A., Adjatin, A., Agbangla, C. and Dansi, A. (2017). Agro-morphological characterization of chili pepper landraces (Capsicum annuum L.) cultivated in Northern Benin. Genetic Resources and Crop Evolution, 1-15.

Radhouane, L. (2004). Etude de la variabilitémorphophénologique chez Pennisetum glaucum (L.) R. Brit. Plant Genetic Resources Newsletter, 138: 18-22

Shannon, C.E. and Weaver, W. (1964). The Mathematical Theory of Communication, The University of Illinois, Chicago. Pp.125. 
Smith, S.E., Doss, A.A. and Warburton, M. (1991). Morphological and agronomic variation in North African and Arabian alfalfas. Crop Science, 31: 1159-1163

Sugiyama, M., Sato, H., Matsushima, K., Paudel, M.N., Shrestha, D.S. and Karkee, A. (2018). Collaborative exploration of Capsicum and Cucurbitaceae vegetable genetic resources in Eastern Nepal, February 2018. AREIPGR, 34: 215-227.

Tolbert, D.M., Quslset, C.O., Jain, S.K. and Craddock, J.C. (1979). A diversity analyses of a world collection of barley. Crop Science, 19: 789-794.

Yadav, R.K., Gautam, S., Palikhe, E., Joshi, B.K., Ghimire, K.H., Gurung, R., Adhikari, A.R., Pudasaini, N. and Dhakal, R.(2018). Agro-morphological diversity of Nepalese naked barley landraces. Agriculture and Food Security, 7:86.

Yang, R.C., Jana S. and Clark, J.M. (1991). Phenotypic diversity and association of some potentially drought-related characters in Durum wheat. Crop Science 31:1484-1491.

Yatung, T., Dubey, R.K., Singh, V. and Upadhyay, G. (2014). Genetic diversity of chilli (Capsicum anпиит L.) genotypes of India based on morpho-chemical traits. Australian Journal of Crop Science, 8(1): 97-102. 